\title{
Islamic Philanthropy and Civil Society Development Solutions in Indonesia
}

\author{
Dzulkifli Hadi Imawan \\ Department of Ahwal Syakhsiyyah, \\ Faculty of Islamic Studies \\ Islamic University of Indonesia \\ Yogyakarta, Indonesia \\ dzulkifli.hadi.imawan@uii.ac.id
}

\author{
M Muslich K S \\ Department of Ahwal Syakhsiyyah, \\ Faculty of Islamic Studies \\ Islamic University of Indonesia \\ Yogyakarta, Indonesia
}

\author{
Muhammad Roy R Purwanto \\ Department of Ahwal Syakhsiyyah, \\ Faculty of Islamic Studies \\ Islamic University of Indonesia \\ Yogyakarta, Indonesia
}

\begin{abstract}
This paper discussed Islamic philanthropy as a solution to the development of a civil society in Indonesia. Muhammad SAW's teachings of Islamic philanthropy has been proven in history to be a solution to the awakening of Muslims in building a prosperous, educated and civilized society.Therefore, this paper attempted to analyze the urgency of Islamic philanthropy as a solution to the development of an advanced and civilized Islamic society in Indonesia. The information obtained from various literature sources related to Islamic philanthropy were analyzed in this research study. The results of this study showed that the existence of laws on Islamic philanthropy, cooperation between the government and Indonesian Islamic organizations in socializing Islamic philanthropy, and the expounded understanding of philanthropic meanings and purposes for their application in this recent times are important solutions to the development of a civil society in Indonesia.
\end{abstract}

Keywords - Islamic Philanthropy, Civil Society, Development Solution, Indonesia

\section{INTRODUCTION}

The Islamic religion was first revealed by Muhammad SAW, the messenger of Allah. This religion teaches love to Allah's creatures. The Quran says:: "And we have sent You (O Muhammad) but as a Mercy for the 'Alamîn (mankind, jinns and All that exists)" (Al-Anbiya ': 107). The hadith narrated by Abu Hurairah, Muhammad SAW states that: "Verily I am sent as a mercy". (HR. Muslim) [1]. Some of the teachings of Muhammad SAW include philanthropy or charity, loving and sharing with others and sympathizing and empathizing with others. This is one of the pillars in Islam that must be carried out by every Muslim. As Muhammad SAW said, "Islam is built on five bases, testifying that there is no god but Allah and Muhammad is a servant and messenger of Allah, establishing prayer, paying zakat (Islamic philanthropy), pilgrimage to the baitullah and fasting for Ramadan". (HR. Muslim) [1].

Moreover, Muhammad SAW's teachings of Islamic philanthropy has been proven in history to be a solution to the awakening of Muslims in building a prosperous, educated and civilized society. It is one of the possible solutions to building an advanced and civilized Islamic society in Indonesia. This paper explains how the Islamic philanthropy taught by Muhammad SAW can be a solution to building an advanced and civilized society in Indonesia.

\section{PhILANTHROPY IN AN ISLAMIC PERSPECTIVE}

The word philanthropist in the Indonesian Dictionary is defined as a lover of humanity or a or a generous person. The word philanthropy can be defined aslove for others [2][3]. It is a term taken from the Greek words 'philein' which means love) and anthropos (which means human). In Arabic, the term affection or generous is called rahmah, sakha 'or sakhawah [4].

Philanthropy and charity are some of the teachings taught by Muhammad SAW to his people. He is known for spreading love and giving donations to others long before he was appointed as a prophet. Khadijah explained that an angel called Jibril delivered the first revelation to Muhammad SAW in Hira cave, "By Allah, Allah will not trouble you, because you like to spread affection to others, help people who are distressed and unable, glorify guests, and spread other goodness "[5] [6].

Muhammad SAW stressed that loving others, prioritizing the needs of others and helping those in need are one of the main missions of his apostleship. As Muhammad said,: "Verily, I am sent to perfect morals" [7][8]. Muhammad also said ,; "People who like to spread affection, then he will be loved by God who is merciful, therefore spread love to all humans so that Allah will spread love to you" [9][10].

Likewise, Muhammad SAW explained to his followers that philanthropy is a symbol of faith and the glue of brotherhood that results in inner peace and happiness in the world and hereafter (heaven). "Who believe In the Ghaib and perform As-Salât (Iqâmat-as-Salât), and spend out of what we have provided for them" (Al-Baqarah: 3). "And march forth In the Way (which leads to) Forgiveness from Your Lord, and for Paradise as wide as are the heavens and the earth, prepared for Al-Muttaqûn. Those who spend [in Allâh's Cause - deeds of charity, alms, etc.] In prosperity and In adversity, who repress anger, and who Pardon men; Verily, Allâh loves AlMuhsinûn (the good-doers)." (Ali Imran: 133-134).

Muhammad said,: "Whoever excludes others from the troubles of the world, then Allah will expel you from the tribulations of the Judgment Day, and whoever closes the disgrace of a Muslim in the world, Allah will close your disgrace in the world and the hereafter, and whoever makes it easy for someone who is in trouble then Allah will facilitate you in the world and the hereafter. And if you help your brothers then Allah will always help you" (HR. Ibn Majah) [11]. 
Some of the philanthropic teachings of Muhammad SAW include zakat, infaq, shadaqah, and also waqf. These philanthropic orders are widely explained in the Prophet's hadiths and traditions, including the Word of God:

"And perform As-Salât (Iqâmat-as-Salât), and give Zakât, and Irka' (i.e. bow down or submit yourselves with obedience to Allâh) along with Ar-Raki'ûn. (Al-Baqarah: 43)

"O You who believe! spend of the good things which You have (legally) earned, and of that which we have produced from the earth for you, and do not aim at that which is bad to spend from it, (though) You would not Accept it save if You close Your eyes and tolerate therein and know that Allâh is rich (Free of All wants), and Worthy of All praise." (AlBaqarah: 267)

"And it is $\mathrm{He}$ who produces Gardens trellised and untrellised, and date-palms, and crops of different shape and taste (its fruits and its seeds) and olives, and pomegranates, similar (in kind) and different (in taste). Eat of their fruit when they ripen, but pay the due thereof (its Zakât, according to Allâh's orders 1/10th or 1/20th) on the Day of its harvest, and waste not by extravagance. Verily, He likes not Al-Musrifûn (those who waste by extravagance), (Al-An'an: 141)

"Take Sadaqah (alms) from their wealth In order to purify them and sanctify them with it, and invoke Allâh for them. Verily! Your invocations are a source of security for them, and Allâh is All-Hearer, All-Knower”. (At-Taubah: 103)

"By no means shall You attain Al-Birr (piety, righteousness, etc., it means here Allâh's Reward, i.e. Paradise), unless You spend (in Allâh's Cause) of that which You love; and whatever of good You spend, Allâh knows it well." (Ali Imran: 92)

"And those Who, before them, had homes (in AlMadinah) and had adopted the Faith, love those who emigrate to them, and have no jealousy In their breasts for that which they have been given (from the booty of Banî An-Nadîr), and give them (emigrants) preference over themselves, even though they were In need of that and Whosoever is saved from his own covetousness, such are they who will be the successful. (Al-Hasyr: 9)

Muhammad said, "Islam is built on five bases, those are testifying that there is no god but Allah and Muhammad is a servant and messenger of Allah, establishing prayers, paying zakat, pilgrimage to the Baitullah and fasting for Ramadan". (HR. Muslim) [1]. Such philanthropy was practiced in the early period of Islam, especially after Muhammad moved to Madinah to build a civilized society. Muhammad (SAW) was a prime example in philanthropy, he never turned down any of those who asked him for help. Abu Said al-Khudri narrated that each time Ansar asked for Muhammad SAW's treasure, he willingly gave it to them till he had nothing leftto save "[7].

Muhammad SAW taught his followers the principle of philanthropy; he explained that the hands above are better than the hands below, (i.e. people who give are better than people who ask for or receive gifts) [1]. This principle was copied and practiced by his friends to the extent that they began to compete in giving and sharing with others. For instance, Umar bin Khattab commemorated half of his property while Abu Bakr gave his entire property [12]. Also, Usman Bin Affan (who did not want to lose to these two) gave out 1000 dinars,
900 camels, and 100 horses when Muslims were experiencing famine [5].

In addition, other friends who had a lot of wealth use it for the benefit of Muslims. For instance, Abu Talha (one of the richest people of the Ansar tribe) endowed the best date garden called Bairaha 'which was located in front of the Prophet's Mosque [13][14], Banu Najjar consecrated a land to be used as a mosque by Muhammad SAW [6], Usman Bin Affan endowed the Romah well for the needs of Muslims [15], and Umar also endowed his best land in Khaibar [1].

During this period, these behaviors encouraged the people of Medina to rise up and build the economy, education, politics and a materialized civilized society (Madani) in Medina al-Munawwarah [16]. The Muslims commenced the development of civilizations initiated by Muhammad SAW in Khulafaurrasyidin (632-661M), Umayyad Dynasty in Damascus (661-749M), Abbasid Dynasty in Baghdad (7491258M), Umayyah II Dynasty in Andalusia (Spain) (750 1492M), and Ottoman Turks in Constantinople (1231-1924M) [17].

Philanthropic practices in Islam have played an important role in the development of civilized Islamic societies. As time goes by, Islamic philanthropy develops according to the time and conditions of a place in order to ensure that the objectives of Islamic philanthropy are maximizedin a more productive direction for the welfare of mankind.

\section{ISLAMIC PHILANTHROPY AND CIVIL SOCIETY DEVELOPMENT SOLUTIONS IN INDONESIA}

The following steps can be taken to develop Islamic philanthropy such as zakat, infaq, sadaqah and endowments in Indonesia:

\section{A. The Establishment of Law and Philanthropic Fund Management Institution}

As stated by al-Qardlawi, some of the conditions that determine the success of Islamic philanthropy in the realization of social justice and welfare of the people include government support (ulil amri) and professional philanthropic management (husnu al-idarah) [18]. Thus, the Indonesian Government have formulated laws related to philanthropy and support the establishment of special bodies or professional institutions that are in charge of the management of Islamic philanthropy. This includes the law of the Republic of Indonesia Number 23 of 2011 concerning the management of zakat, which includes the deployment of the urgency of the National Zakat Agency (a.k.a. BAZNAS). It fosters the collection, distribution and utilization of zakat [19].

In addition, there are 15 institutions of amil zakat (LAZ), and 3 Institutions of Zakat, Infaq and Shadaqah (LAZIS) which have been recognized by the state or the Directorate General of Taxation, namely, LAZ Dompet Dhuafa, LAZ Amanah Takaful Foundation, LAZ PKPU, LAZ Baitulmaal Muamalat, LAZ Al Falah Social Fund Foundation, LAZ Baitul Maal Hidayatullah, LAZ Islamic Union, LAZ Baitul Mal Muslim Community PT BNI Foundation, LAZ Yayasan Bangun Sejahtera Mitra Umat Foundation, LAZ Council Da'wah Islamiyah Indonesia, LAZ Baitul Mal BRI Foundation, LAZ Foundation Baitul Mal Wat Tamwil, LAZ Baituzzakah Pertamina, LAZ Wallet Caring for Darut Tauhid People (DUDT), LAZ Yayasan Rumah Zakat Indonesia, 
LAZIS Muhammadiyah, LAZIS NU, and LAZIS IPHI (Indonesian Hajj Brotherhood Association).

The government also issued regulations on waqf which became one of the important philanthropies in Islam. Regulations on endowments have existed since the Dutch period from 1903 to 1935. However, the waqf regulation grew positively with the issuance of the Ministry of Religion regulation on December 22, 1953 concerning the procedure for the grant of waqf land, which was later rearranged by a circular of the department of religion no. 5 / D / 156. The Law No. $5 / 1960$ concerning the basic rules of agrarian principles was then issued. In this law, waqf assets have a permanent legal basis; the state officially states the protection of waqf property. After the development of Act No. 41 of 2004 concerning endowments with the main objective to encourage the progress of the management of waqf in Indonesia, the waqf sector is expected to function to support the socio-economic welfare of Muslims [20].

The government also monitors Islamic philanthropic management institutions through the selection and fulfillment of a set of criteria or mandate, professional and transparent delivery, with the aim of controlling coordinative, consultative and informative work relations. Thus, philanthropic management institutions are responsibleto the government and to the wider community. This supervision can be used to obtain information about philanthropic management, philanthropic management institutions, suggestions and/or opinions to philanthropic management institutions as well asreports on the occurrence of deviations from philanthropic management [21]. With the regulations of the Indonesian government and special institutions or agencies dealing with Islamic philanthropy, the collection of relevant information in Indonesia can be more orderly and directed to improve the economy, as well as education or other good programs.

\section{B. Cooperation between the Government and Indonesian Islamic Mass Organizations in Socializing Islamic Philanthropy}

It is quintessential to receive attention and support from the ulamas, Islamic organizations (such as Muhammadiyah, Nahdlatul Ulama, Nahdlatdul Wathan, PERTI, and Washliyah) that have a very large mass base throughout the archipelago, as well as the cooperation of preachers who preach in mosques in order to socialize Islamic philanthropy as a solution to the improvement of the economy and development of a more advanced and civilized society,.

\section{Expanding Islamic Philanthropy Rules}

One of the rules of usul al-Figh saysthat legal changes are influenced by changes in times [22]. Thus, the realization of Islamic philanthropy goals in the society is dependent on the use of new rules generated from the expounded understanding or form of today's Islamic philanthropy. In the past, people shared a theme with each other in order to meet their needs in a consumptive manner. These ideas were then directed to productive people. Al-Qardlawi stated that the main purpose of Islamic philanthropy is not only to give food or money, but to provide a more decent and better life to people [18].

Therefore, the distribution of Islamic philanthropy is not only consumptive but also productive. The word fi sabilillah in At-Taubah verse 60 of al-Tafsir al-Kabir written by Imam Fakhruddin Ar-Razi, does not only mean people fighting on the path of Allah, it also means making fortifications, making mosques amongst others.

The different forms of Islamic philanthropy distribution can be used to make water sources that are channeled to the community, public services such as the construction of highways and bridges, rest areas for resorts that have bathrooms and prayer rooms, the coaching of children, women or people who have a psychological burden, assisting victims of natural disasters, the establishment of schools, Islamic boarding schools, universities, the and libraries, scholarships for students, as well as for the construction of health centers such as community health centers, hospitals and environmental preservation (which include hygiene land, water, and parks).

Furthermore, the building of shops, supermarkets, traditional markets, mini markets, Islamic banks, BMT and others needs is notable form of Islamic philanthropy. The advancement of the global era has necessitated the development of Muslim communication media such as radio, television, internet and other information technologies that require a lot of funding. Thus, the distribution of Islamic philanthropy to these sectors will result in the growth and development of the economy. This is as a rule in Ushul alFigh, maati yatimmu al-obligatory ila bihi fa huwa obligatory, obligations that cannot be done except by that wasilah, then it becomes an obligation to be held. Financial securities can also be a driving force for Islamic philanthropy, coupled with the existence of management institutions that work towards the development of an advanced and civilized Islamic society in Indonesia.

\section{CONCLUSION}

This article shows a number of changes that can be made to enhance the role of Islamic philanthropy in Indonesia. These changes may occur in the aspects of legislation, cooperation with mass organizations, and the expansion of the meaning of philanthropy.

\section{REFERENCES}

[1] Muslim 2006 Al-Musnad al-Shahih al-Mukhtashsar Shahih Muslim (Beirut: Dar Ihya Turats Arabiy)

[2] Departemen Pendidikan dan Kebudayaan 1996 Kamus Besar Bahasa Indonesia Edisi Kedua (Jakarta: Balai Pustaka)

[3] Hawkins J M 1996 Kamus Dwibahasa Oxford (Jakarta: Penerbit Erlangga)

[4] Munawwir A W 1997 Kamus al-Munawwir Arab-Indonesia Terlengkap (Surabaya: Pustaka Progessif)

[5] Al-Mubarakfuri S 1987 Ar-Rahiq al-Makhtum (Riyadh: Dar Al Salam)

[6] Al-Bukhari 1987 Al-Jami' al-Shahih al-Mukhtashar (Beirut: Dar Ibnu Katsir)

[7] Al-Baihaqi 1990 Syu'abu al-Iman (Beirut: Dar al-Kutub al-'Ilmiyah)

[8] Qadli Iyadl 1988 Al-Syifa' bi Ta'rif Huquq al-Musthafa (Beirut: Dar al-Fikr)

[9] Al-Tirmidzi 1975 Sunan Tirmidzi (Cairo: Musthafa Bab Halabi)

[10] Abu Dawud 1990 Sunan Abu Dawud (Beirut: Maktabah Ashriyah)

[11] Al-Qaznawi 1992 Sunan Ibnu Majah (Beirut: Dar al-Fikr)

[12] Al-Darimi 1987 Sunan al-Darimy (Beirut: Dar Al Kitab Al-'Arabi)

[13] Ibnu Katsir 1999 Tafsir al-Qur'an al- 'Azhim (Beirut: Dar Thayyibah)

[14] Ibnu Hibban 1993 Shahih Ibni Hibban (Beirut: Muassasah Al-Risalah)

[15] Al-Tabraniy 1983 Al-Mu'jam Al-Kabir (Mosul: Maktabah Ulum wa Hikam)

[16] Al-Buthi R 1991 Fiqh Al-Shirah Al-Nabawiyyah ma’a Mujiz li Tarikh Al-Khilafah Al-Rasyidah ( Beirut: Dar Al-Fikr Al-Mu'ashir) 
[17] Syalabi A Z 2012 Tarikh Al-Hadlarah Al-Islamiyah wa Al-Fikr AlIslamiy (Cairo: Maktabah Wahbah)

[18] Al-Qardlawi Y 1973 Fiqh Al-Zakah (Beirut: Muassasah Al-Risalah)

[19] Government of Republic of Indonesia 2011 Undang-Undang No. 23 Tahun 2011 tentang Pengelolaan Zakat (Jakarta: Government of Republic of Indonesia)

[20] Kasdi A 2017 Fikih Wakaf: Dari Wakaf Klasik Hingga Wakaf Produktif [Fiqh of Waqf: From Classical to Productive Waqf] (Yogyakarta: Idea Press)
[21] Kementrian Agama RI 2012 Pedoman Pengawasan Lembaga Pengelola Zakat [Guidelines for Zakat Organisation Supervision ] (Jakarta: Direktorat Jenderal Bimbingan Islam Direktorat Pemberdayaan Zakat)

[22] As-Sullami I N 2005 Ushûl al-Fiqh al-Ladzi La Yasa'u al-Faqîh Jahluh (Riyadh: Dar at-Tadmuriyyah) 